\title{
Fermentation of Multi-targeted Products: A Statistical Approach Discussed the Production of Cell Wall Hydrolytic Enzymes From Streptomyces Rochei for Control of Pathogenic Fungi
}

Eman Elgammal ( $\sim$ emanelgammal50@yahoo.com )

National Research Centre https://orcid.org/0000-0002-2647-4875

Eman Ahmed

National Research Centre

Mohamed Abdel Aziz

National Research Centre

\section{Research Article}

Keywords: Multi-cell wall lytic enzymes, Streptomyces rochei, biological control, low cost substrates, statistical modeling

Posted Date: July 9th, 2021

DOl: https://doi.org/10.21203/rs.3.rs-641022/v1

License: (a) (1) This work is licensed under a Creative Commons Attribution 4.0 International License.

Read Full License 


\section{Abstract}

The production of synergistically multi-acting cell wall hydrolyzing enzymes was observed in the culture filtrate of a strain molecularly characterized as Streptomyces rochei MZ227230. It showed high ability to produce chitinase, glucanase, protease and whole cell-wall lytic enzymes "WCL". The simultaneous optimization production of several enzymes is a true challenge since each enzyme has its own favorable requirements that may not support or contradict the production of the others. Thus, the current study discussed such issue through application of statistical modeling. Productivity of the enzymes was monitored in different media and superiority of the modified TLE medium (M4) was clearly noticed. BoxBehnken design (BBD) using the key components of M4 (C. albicans cell walls, baker yeast, chitin and peptone) followed by independent analysis for productivity of each enzyme helped to conduct four significant models describing four media that were specifically optimized to produce the utmost yields of chitinase (14.97), glucanase (27.89), protease (137.59) and WCL (65.28 U/ml). Pearson's correlation analysis indicated the impossibility to potentiate the tested enzymes to the utmost yields at the same time. However, simultaneous solution for all models' equations identified a coproduction medium that potentiated more than $80 \%$ of the maximal yields for all enzymes. Finally, the crude filtrate showed potent fungicidal effects against Fusarium graminearum, Mucor racemosus, Fusarium solani, and Candida albicans which were proven to be attributed to the hydrolytic activity of the filtrate basing on dose and time-dependent release of $C$. albicans cell constituents DNA, RNA and protein as a model microbe.

\section{Introduction}

Lytic enzymes or cell wall degrading enzymes are consisting mainly of more than one enzyme such as glucanase, chitinase and protease which are able to hydrolyze glucans, chitin and proteins as the main skeletal components in fungal cell wall by acting synergistically to hydrolyze the pathogen cell wall $[1,2]$. The synergistic effect starts with protease which acts on cell wall protein to open its structure and expose the inner layer of glucan and chitin to be attacked by glucanase and chitinase forming a big hole in the cell wall and plasma membrane [3]. Therefore, this system of enzymes can be categorized as biological control agents [4] and considered as ecofriendly products [5]. They are produced from different microorganisms as antagonistic key factors against several pathogens $[2,6]$.

Lytic enzymes have broad industrial applications such as extraction of proteins, enzymes and carbohydrates, protoplast formation, control of pathogenic fungi and degradation of yeast cell mass [7]. So, lytic enzymes as safe and effective natural products have the priority to apply in the field of biological control of plant diseases instead of the chemical fungicides which can accumulate in the animal and human food causing high toxicity [5]. Furthermore, they can be applied as antimicrobial agents against the multidrug resistant microbes. Since the antimicrobial resistance patterns are partly dependent on their mechanism of action, so the mode of action must be investigate [8].

Targeting more than one type of lytic enzymes to be simultaneously optimized is highly advantageous; it could strongly potentiate the antifungal activity of studied microbial culture and will afford fermentation 
of multiple financial returns. However, simultaneous optimization of many products in the same fermentation (fermentation of multi-targeted products) has some practical constrictions; each of coproducts has its own favorable requirements that may not support or even contradict the production of others, and so simultaneous optimization may achieve an increase in the production of each product yet to level that is more or less close to the maximum yield obtained at fermentation of mono-targeted product.

Many investigators were engaged with optimization studies on co-production of several products $[9,10,11,12,13]$ yet they did not compare the yield obtained under simultaneous optimization with the yield obtained under single-product optimization. The question of "to how extent could the yield of a product in a fermentation of multi-targeted products be close to the yield obtained in fermentation of mono-targeted product" is well valued for assessing the economic feasibility of fermentation of multitargeted products and of course will encourage more future studies aiming at getting more proficiency in such fermentation. As such, the current study targeted the simultaneous optimization in production of some lytic enzymes through the effective tool of statistical modeling and evaluated the efficiency of optimization by comparing the yields obtained with those attained in mono-targeted fermentation. The study has also extended to apply the culture containing maximum coexistence of lytic enzymes in in-vitro control of some pathogenic fungi and followed the release of vital fungal cell constituents.

\section{Materials And Methods}

\section{Microorganisms, growth conditions and inoculum preparation}

Some soil Streptomyces isolates were screened for lytic enzymes production using modified TLE medium [14]. The modified medium is containing $\%\left(\mathrm{~K}_{2} \mathrm{HPO}_{4}: 0.3, \mathrm{KH}_{2} \mathrm{PO}_{4} ; 0.2, \mathrm{MgSO}_{4} .7 \mathrm{H}_{2} \mathrm{O}: 0.03\right.$, Peptone: 0.05 , Glucose: 0.02 , Chitin: 0.1 , Baker yeast: $0.5, \mathrm{NaNO}_{3}: 0.1$ and cell wall of $C$. albicans: 0.3 ). The enzyme system production was determined after 4 days of incubation at $30^{\circ} \mathrm{C}$ and $200 \mathrm{rpm}$. The most potent organism [isolate 20S] was grown in ISP2 agar slants for 5 days at $30^{\circ} \mathrm{C}$ and kept at $4^{\circ} \mathrm{C}$. Then, two $\mathrm{mL}$ of the spore suspension $\left(10^{6} \mathrm{CFU} / \mathrm{ml}\right)$ were inoculated into $50 \mathrm{ml}$ of the fermentation medium. The cultures were incubated in a shaking incubator at $200 \mathrm{rpm}$ for 4 days at $30^{\circ} \mathrm{C}$. After that, the enzymatic activity was determined in cell free supernatant.

\section{Identification of the most potent organism using 16S rRNA method}

Molecular identification of isolate 20S using 16S rRNA method was done according to Sigma Scientific Services Company method as follows:

DNA extraction was made by Quick-DNA Bacterial/Fungal Micro-prep Kit (Zymo research \#D6007). Then PCR cleanup to the PCR product was made by using the GeneJET PCR Purification Kit (Thermo K0701) (Thermo Fisher Scientific, Waltham, Massachusetts, USA). Finally, the sequencing was made to the PCR product on GATC Company by an ABI 3730xI DNA sequencer using forward and reverse primers. 


\section{Assay of lytic enzymes}

\section{Preparation of cell wall substrate}

Five liters of heat killed $C$. albicans were sonicated and centrifuged then the residual cell walls were washed then lyophilized and stored according to Valois et al. [15].

\section{Turbidimetric method}

Whole cell-wall lytic activity (WCL) was detected by measuring the lysis extent of heat-killed C. albicans suspension at $660 \mathrm{~nm}$ according to Tominaga and Tsujisaka [16] with some modifications in volumes of the reaction mixture. One unit of lytic activity is defined as a change in absorbance of 0.001 at $660 \mathrm{~nm}$ of a heat-killed suspension of $C$. albicans per hour.

\section{Glucanase assay}

The enzyme activity was detected spectro-photometrically by 3,5-dinitrosalicylic acid reagent (DNS) method [17]. The reaction mixture containing $0.5 \mathrm{ml}$ enzyme and $50 \mu$ laminarin ( $2 \%$ dissolved in $50 \mathrm{mM}$ sodium acetate buffer, $\mathrm{pH} .5 .0$ ) was incubated for $30 \mathrm{~min}$ at $37^{\circ} \mathrm{C}$ followed by addition of $3 \mathrm{ml} \mathrm{DNS}$ reagent to stop the reaction. After boiling in water bath for $10 \mathrm{~min}$, the reducing sugar was measured at $540 \mathrm{~nm}$. One unit of enzyme $(U)$ was defined as the amount of protein necessary to produce one microgram of reducing sugar per min.

\section{Chitinase assay}

$\mathrm{N}$ - acetyl hexosaminidase activity was detected according to Coudron et al. [18]. A sample of $50 \mu \mathrm{L}$ of enzyme filtrate was added to $50 \mu \mathrm{L}$ of p-Nitro phenyl- $\beta$ - $\mathrm{N}$-acetylglucosaminide $(1 \mathrm{mg} / \mathrm{mL}$ in $0.05 \mathrm{M}$ acetate buffer, $\mathrm{pH} 5$ ) and mixed then incubated in shaking water bath for 1 hour at $30^{\circ} \mathrm{C}$. The reaction was stopped by addition of $2.5 \mathrm{~mL}$ of $0.125 \mathrm{M}$ sodium borate buffer $(\mathrm{pH} 10)$. The amount of the released p-nitro phenol was measured spectroscopically at $410 \mathrm{~nm}$. One unit of the enzyme activity was defined as the amount of enzyme that releases $1 \mu \mathrm{mol}$ of p-nitro phenol per min under the specified assay conditions.

\section{Protease assay}

Protease activity was determined in the culture filtrate using casein as a substrate, by the modified procedure of Tsuchida et al. [19] method. Equal volumes $(0.5 \mathrm{ml})$ of enzyme solution and substrate solution $(2 \% \mathrm{w} / \mathrm{v}$ casein in $50 \mathrm{mM}$ Sodium phosphate buffer $\mathrm{pH} 7)$ were mixed and incubated at $37^{\circ} \mathrm{C}$ for 30 minutes. To stop the reaction; $1 \mathrm{ml}$ of $5 \%(\mathrm{w} / \mathrm{v})$ trichloroacetic acid was added then incubated in ice for 15 minutes. The insoluble proteins were precipitated by centrifugation and the acid soluble supernatant was neutralized by adding $5 \mathrm{ml}$ of the alkaline $\mathrm{Na}_{2} \mathrm{CO}_{3}$ solution $(0.5 \mathrm{M})$. Finally, $0.5 \mathrm{ml}$ of two fold diluted Folin Ciocalteau reagent was added then the mixture was incubated at room temperature for 30 minutes. 
The absorbance was measured at $750 \mathrm{~nm}$. One protease unit is defined as the amount of enzyme that releases $1 \mathrm{mg}$ tyrosine per $\mathrm{ml}$ per minute under the above assay conditions.

\section{Optimization of fermentation conditions}

\section{Effect of different media}

Modified media ( $\mathrm{g} / \mathrm{l})$

M1: Baker yeast; $5, \mathrm{NaH}_{2} \mathrm{PO}_{4}: 1[20]$.

M2: Reynold's medium: $\mathrm{K}_{2} \mathrm{HPO}_{4} ; 0.7, \mathrm{KH}_{2} \mathrm{PO}_{4} ; 0.3, \mathrm{MgSO}_{4} ; 0.5, \mathrm{FeSO}_{4} ; 0.01, \mathrm{ZnSO}_{4} ; 0.001$, cell wall of $C$. albicans; 5 [21].

M3: Starch nitrate: Starch; 20, $\mathrm{KNO}_{3} ; 2, \mathrm{KH}_{2} \mathrm{PO}_{4} ; 1, \mathrm{MgSO}_{4} ; 0.5, \mathrm{NaCl} ; 0.5, \mathrm{CaCO}$; 3 , FeSo4; 0.01; cell wall of C. albicans; 2 [22].

M4: Modified TLE medium: As mentioned above [14].

\section{Statistical design and modeling}

Box-Behnken design, analysis of variance (ANOVA) of data, regression analysis to get coefficients in the most fit equations and predictions of the optimum levels of variables were achieved using the "Design Expert》 software (Version 7.0.0, Stat-Ease Inc., Minneapolis, USA) statistical package. Pearson's correlation coefficient ( $r$ ) was determined by Microsoft Office Excel 2007.

\section{In vitro antifungal effect}

\section{Test microorganisms and inocula preparation}

Some plant pathogenic fungi such as Fusarium graminearum, Alternaria betroselini, Mucor racemosus, Fusarium solani, and Candida albicans were kindly provided from Chemistry of Natural and Microbial Products, National Research Center. The strains were grown and kept on PDA slants at $4^{\circ} \mathrm{C}$. To prepare inoculum, a loopful of 2-5 days old cultures was transferred into sterile saline solution to provide a final concentration of approximately $10^{6} \mathrm{CFU} / \mathrm{mL}$ adjusted according to the turbidity of $0.5 \mathrm{McF}$ arland scale tube at $600 \mathrm{~nm}$.

\section{Antifungal assay}

The culture filtrate of the most potent isolate obtained from the previous step was tested for its antifungal activity by using agar well diffusion method [23]. After preparing of PDA medium and sterilization, the medium was cooled to $47^{\circ} \mathrm{C}$ and then poured in sterilized Petri dishes $(9 \mathrm{~cm})$ containing $100 \mu \mathrm{l}$ of different inocula. After solidification, $10 \mathrm{~mm}$ wells were made and loaded with $100 \mu \mathrm{l}$ of the crude culture filtrate which was sterilized by passing through bacterial filter membrane. Then the 
inoculated plates were incubated for $48 \mathrm{~h}$ at $30^{\circ} \mathrm{C}$. The inhibition zone diameter expressed in millimeters $(\mathrm{mm})$ was detected by measuring against ketoconazole $(0.5 \mathrm{mg} / \mathrm{mL})$ as standard antifungal.

\section{Mechanism of action of crude multi-lytic enzymes depending on cell membrane integrity}

Cell membrane integrity of $C$. albicans was detected by quantification of cellular constituents released from the cell to outside medium. Different concentrations of sterilized crude lytic enzymes $(100 \%, 75 \%$, $50 \%$ and $25 \%$ ) which contain $1 \mathrm{mg}$ protein $/ \mathrm{ml}$ were prepared and diluted in phosphate buffer saline. Then

the inoculum $\left(10^{5} \mathrm{CFU} / \mathrm{ml}\right)$ was suspended in $5 \mathrm{ml}$ saline and then $100 \mu \mathrm{l}$ of it were added to the tested concentrations after that the samples were incubated at $30^{\circ} \mathrm{C}$ for $6 \mathrm{~h}$. Samples were taken after 3 and $6 \mathrm{~h}$ and centrifuged for 5 min then the filtrate was collected and measured using NanoDrop to detect the concentration of DNA, RNA, and protein released [24].

\section{Results And Discussion}

\section{Screening for production}

During a screening course on the production of several hydrolytic enzymes by some soil Streptomycetes, one of the isolates (assigned as 20S) showed remarkable ability to produce multi-lytic enzymatic system included chitinase, glucanase and protease besides remarkable enzymatic activity in hydrolysis of whole cell wall of the yeast Candida albicans. Basing on synergistic action of the four enzymes, strain 20S was able to show wide inhibition zone around its colonies in baker-yeast seeded medium which reflected its intense antifungal activity (Fig. 1).

\section{Molecular identification by $16 \mathrm{~S}$ rRNA}

The strain was molecularly characterized and its 16S rRNA gene sequence (accession number: MZ227230 in NCBI gene bank) showed close similarity to Streptomyces rochei as depicted in phylogenetic tree (Fig. 2). As it was assumed that simultaneous increase in production of the hydrolytic enzymes could strongly potentiate antifungal activity, the improvement in their production was concomitantly intended during subsequent investigations.

\section{Production of hydrolytic enzymes in different fermentation media}

Enzyme production is highly affected by composition of fermentation medium. As such, productivity of hydrolytic enzymes was monitored in four different media. From Table 1, it was observed that the activity values of glucanase, protease and chitinase were varied considerably depending on the composition of the applied medium and substrate added to the medium [25]. The medium (M4) supplemented with chitin, baker yeas (glucan substrate) and Candida albicans cell wall was the best ones for biosynthesis of the three enzymes due to the presence of the inducer as main sources of carbon [26]. Also, the results revealed that activity of protease is higher than glucanse and chitinase in all tested media, this may be due to the presence of yeast biomass or baker yeast which can induce good expressions for protease 
[27]. As the dry matter of yeast cell wall contains about $28 \%$ of glucan and $11 \%$ of chitin [28] in addition to $40 \%$ protein [29], it was noticed that all tested media produced the enzymes protease, glucanase and chitinase in an amounts reflected their the abundance of their substrates in dry matter of yeast cell wall.

\section{Statistical optimization for maximizing the production of each enzyme}

Superiority of medium M4 over other tested media was assumed to be attributed to its contents of the four main components of chitin, baker's yeast, Candida cell walls and peptone. The four components play crucial roles as inducers for production of the targeted enzymes. As such, they were undertaken in BoxBehnken design (BBD) to be properly formulated for attaining the highest production of the three enzymes in addition to WCL. The four components were coded and applied at three levels as shown in Table 2. The Box-Behnken design of 27 runs with three center points was conducted and the production of the enzymes was determined at each run as indicated in Table 3. Analysis of variance (ANOVA) of the data in Table 3 has been attained and shown in Table 4. The analysis was carried out independently on each enzyme to identify the model of the highest specialty and fitness to describe the production. The results in Table 4 showed that the production of each enzyme was correlated with the four medium components through a definite model and specific equation describing the production. Regarding the significance and validity, all of the obtained models were statistically significant ( $p$-value less than 0.05 ) and there were low chances that a "Model F-Value" could occur due to noise. Lack of fit was not significant in all models which implies significant fitness of models. Signal to noise ratio "Adeq Precision" was considerably greater than 4 in the four models which indicated an adequate signals and validity to use such models to navigate the design space [30]. In case of chitinase and WCL, the type of the model was the same (quadratic model), however the equations describing the two model were completely different. Simple models of the type linear and two-factor interaction $(2 \mathrm{FI})$ were obtained in case of protease and glucanase respectively. The linear equation describing the production of protease was simple enough to indicate clear positive effect of all components on the enzyme production. Considering the significant terms in all models, it was obviously revealed that the term A (codes for peptone concentration) was significant only in case of protease production while the term $B$ (codes for chitin concentration) was significant only with chitinase production. In such regard, the role of peptone and chitin in production of protease and chitinase respectively was reported in elsewhere [31,32,33,34,35]. However, the terms $C$ and $D$ (code for baker's yeast and cell wall concentrations respectively) were significant in production of many enzymes. Interaction between variables indicates the ability of any of interacting variables to alter the profile of the effect of the other. Regarding the interactions between the different components, the most common was that between $A$ and $D$ (peptone and cell wall concentration) which was realized in production of chitinase, glucanase, and WCL. Other interactions (between C \& D or C \& B) were occasionally noticed.

Ability of the four obtained models to predict the productivity of the enzymes was inferred from the relation between prediceted enzyme concentration versus actual concentration, as depicted graphically in Fig. 3. Distribution of the points around the line of the perfect prediction revealed a reliable predictability. The models were thus employed to find the optimum composition of the maximum production. Response 
surface methodology (RSM) on each of the four models defined the medium composition that was specific for the highest production of the concerned enzyme. Table 5 summarized the composition of a four media basing on different models with expected and verified productivity. As indicated in Table 5, the practical validation of productivity realized high proficiency of BBD and RSM in system prediction and optimization. It was possible to verify the maximum yields of $14.97,27.89,137.59$ and $65.28 \mathrm{U} / \mathrm{ml}$ for chitinase, glucanase, protease and WCL respectively using fermentation media I, II, III and IV specific for each enzyme. Specificity of medium for maximum production of an enzyme varied considerably with slight change in composition as it was inferred from media I and IV.

\section{Correlation between productivities of different hydrolytic enzymes}

The possibility to potentiate the production of more than one enzyme to the highest yield simultaneously (in the same fermentation medium) was realized through degree of correlation between their productivities; the enzymes whose concentrations increase or decrease together are of a positive correlation and more likely to be simultaneously enhanced to highest yield in the same fermentation medium. Pearson's correlation coefficient $(r)$ was calculated for the relation between productions of different enzymes in 27 runs of BBD. As shown in Table 6, there was moderate positive correlation between glucanase and protease production $(r=0.69)$, and with less extent was the relation of chitinase with WCL $(r=0.35)$. Accordingly, it was thought that improving the yield of glucanase moves with good extent in the same direction with increase in protease concentrations, and it is nearly the same case between chitinase and WCL. The results also revealed negative correlation with different degrees between production of some enzymes. The highest negative correlation has appeared between glucanase and WCL $(r=-0.49)$ indicating that increasing the yield of one of them moves with considerable degree in the direction of decreasing the yield of the other which may reflect an inhibitory metabolic mechanisms between such enzymes according to carbon metabolite repression between their inducing substrates [36].

\section{Coproduction of hydrolytic enzymes}

From the preceding data and analysis, it was inferred that each enzyme has its specific favorable requirements that have not potentiated the production of other enzymes by the same extent. Finding a medium that supports the coproduction of all enzymes simultaneously as much as possible and comparing production of each enzyme in such medium with its productivity in its specific optimized medium is the target adopted here. Basing on BBD and RSM, the composition of the main components of the best suited medium for coproduction was identified. The composition of the medium, predicted and verified productivity were presented in Table 7 . The medium could potentiate the productivity to 12.05 , $23.08,130.90$ and $57.00 \mathrm{U} / \mathrm{ml}$ for chitinase, glucanase, protease and WCL respectively which were equivalent to $80.51 \%, 82.73 \%, 95.14 \%$ and $87.32 \%$ of the maximum yield of each enzyme obtained in media I, II, III and IV on respective order. Superiority of coproduction medium was clearly demonstrated when testing suitability of other media (I, II, III and IV) in coproduction. Each of the four media was evaluated for suitability in coproduction by determining the concentration of all enzymes and expressing them as a percentage of the maximum yield obtained for each enzyme in its specifically optimized 
medium, as indicated in Table 8. Though each medium showed highest specificity for maximum production of an enzyme, the medium was of significant poor specificity for some other enzymes whose productivities had significantly dropped to less than $50 \%$. The success in broadening the specificity of the medium, to fulfill the favorable production of all enzymes without uncontrolled drop in each of their yields, clarified the unique surprising privilege of statistical modeling in fermentation technology. Moreover, the ability to produce several products simultaneously with more than $80 \%$ of their maximum yields, even there were some considerable negative correlations between their production, represented a valuable record in fermentation technology and was thought to have deep future implications concerning the financial returns of fermentations.

\section{Investigation of antifungal activity}

The crude culture filtrate of Streptomyces rochei containing the highest richness of all enzymes (in simultaneous existence) had been employed in in-vitro challenge against some pathogenic fungi where intensive antifungal activity was realized with $F$. graminearum $(20 \mathrm{~mm}), M$. racemosus $(13 \mathrm{~mm}), F$. solani $(20 \mathrm{~mm})$, and C. albicans $(25 \mathrm{~mm})$. Similarly, [37] obtained an antagonistic activity of Paenibacillus elgii strain HOA73 against phyto-pathogenic fungi and human fungal pathogens. Also, Philip et al. [38] reported the antagonistic activity against Candida albicans, Aspergillus niger, Microsporum gypseum, Trichophyton rubrum and Saccharomyces cerevisiae through the production of hydrolytic enzymes.

\section{Study of mode of action by testing cell wall integrity}

In the present investigation, $C$. albicans was selected as a target model microbe to study the effect of culture filtrate rich in hydrolytic enzymes from the strain MZ227230 on the integrity of cell wall. The release of $C$. albicans cell constituents under the effect of different concentrations (100, 75, 50 and 25\%) of crude lytic enzymes was investigated to obtain further insight about their mode of action against that pathogen (Fig. 4). The amount of DNA, RNA, and protein released from the cell to the outside medium was dependent on time and enzyme-dose [39]. Where, the maximum amount of leaked constituents reached after $6 \mathrm{~h}$ at the concentration of $100 \%(207 \mathrm{ng} / \mu \mathrm{LNA}, 129 \mathrm{ng} / \mu \mathrm{l}$ RNA and $3.3 \mathrm{mg} / \mu \mathrm{l}$ protein) compared to the untreated control ( $3.6 \mathrm{ng} / \mu \mathrm{l}$ DNA, $2.1 \mathrm{ng} / \mu \mathrm{l}$ RNA and $0.28 \mathrm{mg} / \mu \mathrm{l}$ protein).

These results indicated that lytic enzymes (protease, glucanase and chitinase) acted synergistically to digest the cell wall of $C$. albicans [1] and this effect started with protease which cleave cell wall protein and open it to expose the inner layer of glucan and chitin to be attacked by glucanase and chitinase forming a big hole in the cell wall giving a protoplast which can be lyses immediacy releasing the cell constituents [3]. Thus this multi-enzyme system can be applied for biological control $[4,40]$.

\section{Conclusion}

This study is strongly proved that despite of the simultaneous optimized production of multi-targeted enzymes is a hard challenge, when the maximum yield of each product was targeted in the same 
fermentation medium; the final results revealed that it is possible to obtain about $80 \%$ of the maximum yield of each enzyme at the same time in one fermentation medium. And this also could strongly potentiate the antifungal activity of the produced enzymatic system. Accordingly, this will encourage the economic feasibility of the application of one-step fermentation of different multi-targeted products.

\section{Declarations}

\section{Acknowledgments}

Authors acknowledged Chemistry of Natural and Microbial Products Department, National Research Center.

\section{Author contribution}

Eman W. Elgammal: Conceptualization, Formal analysis, Methodology, Resources, Writing - original draft, Writing - review and editing. Mohamed M. Abdel Aziz: Conceptualization, Data curation, Formal analysis, Methodology, Resources, Software, Writing - original draft, Writing - review \& editing and Software. Eman F. Ahmed: Conceptualization, Methodology, Resources, review and editing.

\section{Funding}

$\mathrm{N} / \mathrm{A}$

\section{Declarations}

$\mathrm{N} / \mathrm{A}$

Consent to Participate

$\mathrm{N} / \mathrm{A}$

\section{Consent for Publication}

We declare that the information in this manuscript has not been published elsewhere nor is it under consideration by any other journal. Furthermore, it is the consensus of all authors to submit this manuscript for possible publication in ABB

\section{Competing interests}

The authors declare no competing interests.

\section{References}

1. Salazar, O., \& Asenjo, J. A. (2007). Enzymatic lysis of microbial cells. Biotechnology Letters, 29, 985994 
2. Giovannoni, M., Gramegna, G., Benedetti, M., \& Mattei, B. (2020). Industrial Use of Cell Wall Degrading Enzymes: The Fine Line Between Production Strategy and Economic Feasibility. Front. Bioengineering Biotechnology, 8, 356

3. Scott, J. H., \& Schekman, R. (1980). Lyticase: endoglucanase and protease activities that act together in yeast cell lysis. $J$ Bacteriology, 142, 414-423

4. Ferrer, P. (2006). Revisiting the Cellulosimicrobium cellulans yeast-lytic beta-1,3-glucanases toolbox: a review. Microbiology Cell Fact, 5, 10

5. Benedetti, M., Locci, F., Gramegna, G., Sestili, F., \& Savatin, D. V. (2019). Green Production and Biotechnological Applications of Cell Wall Lytic Enzymes. Applied Science, 9, 5012

6. Harrison, S. (1991). Bacterial cell disruption: a key unit operation in the recovery of intracellular products. Biotechnology Advances, 9, 217-240

7. Francisco, F., \& Harumi, S. H. (2005). Production, purification, cloning and application of lytic enzymes. Quím. Nova [online], 28, 871-879

8. Tenover, F. C. (2006). 0. Mechanisms of Antimicrobial Resistance in Bacteria. Amer. J of Infection Control, 34(5 Suppl 1):S3-10; discussion S64-73. DOI:10.1016/j.ajic.2006.05.219.

9. Wu, Q., Song, Y. C., Xu, H., Guo, Y., Li, J., \& Tan, R. X. (2011). Medium optimization for enhanced coproduction of two bioactive metabolites in the same fermentation by a statistical approach. $J$ of Asian Natural Production research, 13, 1110-1121

10. Sharma, A., Nain, V., Tiwari, R., Singh, S., \& Nain, L. (2018). Optimization of fermentation condition for co-production of ethanol and 2, 3-butanediol (2, 3-BD) from hemicellolosic hydrolysates by Klebsiella oxytoca XF7. Chemical Engineering Communication, 205, 402-410

11. Limkar, M. B., Pawar, S. V., \& Rathod, V. K. (2019). Statistical optimization of xylanase and alkaline protease co-production by Bacillus spp using Box-Behnken Design under submerged fermentation using wheat bran as a substrate. Biocatalysis and Agricultural. Biotechnology, 17, 455-464

12. Thite, V. S., Nerurkar, A. S., \& Baxi, N. N. (2020). Optimization of concurrent production of xylanolytic and pectinolytic enzymes by Bacillus safensis M35 and Bacillus altitudinis J208 using agroindustrial biomass through Response Surface Methodology. Scientific reports, 10, 1-12

13. Amiri, S., Rezazadeh-Bari, M., Alizadeh-Khaledabad, M., Rezaei-Mokarram, R., \& Sowti-Khiabani, M. (2021). Fermentation optimization for co-production of postbiotics by Bifidobacterium lactis BB12 in cheese whey. Waste and Biomass Valorizat.,1-16.

14. de Marco, J. L., \& Felix, C. R. (2007). Purification and characterization of a beta-Glucanase produced by Trichoderma harzianum showing biocontrol potential.Brazilian archive biological technology, 50 .

15. Valois, D., Fayad, K., Barasubiye, T., Garon, M., Dery, C., et al. (1996). Glucanolytic Actinomycetes Antagonistic to Phytophthora fragariae var. rubi, the Causal Agent of Raspberry Root Rot. Appl. Environ. Microbiology, 62, 1630-1635

16. Tominaga, Y., \& Tsjisaka, Y. (1981). Investigation of the structure of Rhizopus cell with lytic enzymes. Agricultural Biological Chemistry, 45, 1569-1575 
17. Miller, G. L. (1959). Use of Dinitrosalicylic Acid Reagent for Determination of Reducing Sugar. Anal. Chemistry, 31, 426-428

18. Coudron, T. A., Kroha, M. J., \& Ignoffo, C. M. (1984). Levels of chitinolytic activity during development of three entomopathogenic fungi. Comp. Biochem. Physiol. Part B Comp. Biochem, 79, 339-348

19. Tsuchida, O. Y., Yamagata, T., Ishizuka, J., Arai, M., Takeuchi, Y., \& Ichishima, E. (1986). An alkaline protease of an alkalophilic Bacillus sp. Current Microbiology, 14, 7-12

20. Yamamoto, S., Kobayashi, R., \& Nagasaki, S. (1974). Physico-chemical, chemical and enzymatic properties of crystalline yeast cell lytic enzyme from a Rhizopus mold. Agricultural Biol. Chem, 38, 1563-1573

21. Reynolds, D. M. (1954). Exocellular chitinase from Streptomyces spp. J. Genetic Microbiology, 11, 150-159

22. Küster, E., \& Williams, S. T. (1964). "Selective media for isolation of streptomycetes". Nature, London, $203,928-929$

23. Okeke, M. I., Iroegbu, C. U., Eze, E. N., Okoli, A. S., \& Esimone, C. O. (2001). Evaluation of extracts of the root of Landolphia owerrience for antibacterial activity. J Ethnopharmacology, 78, 119-127

24. Desjardins, P. R., \& Conklin, D. S. (2010). Nanodrop microvolume quantification of nucleic acids. $J$ Vis. Exp, 22, 1-5

25. Harman, G. E., Howell, C. R., Viterbo, A., Chet, I., \& Lorito, M. (2004). Trichoderma speciesopportunistic, avirulent plant symbionts. Nat. Rev. Microbiology, 2, 43-56

26. Piegza, M., Szlączka, K., Łaba, W., \& Witkowska, D. (2014). Effect of carbon source on the production of lytic enzymes by filamentous fungi of the trichoderma genus. ejpau 17, 06. Available Online: http://www.ejpau.media.pl/volume17/issue2/art-06.html.

27. Shakeri, J., \& Foster, H. A. (2007). Proteolytic activity and antibiotic production by Trichoderma harzianum in relation to pathogenic to insects. Enzyme Microbiological Technology, 40, 961-968

28. Kramer, K. J., Hopkins, T. L., \& Schaefer, J. (1995). Applications od solid NMR to the analysis of insect sclerotized structure. Insect. Biochem. Molec. Biol, 25, 10667-11080

29. van der Vaart, J. M., Caro, L. H., Chapman, J. W., Klis, F. M., \& Verrips, C. T. (1995). Identification of three mannoproteins in the cell wall of Saccharomyces cerevisiae. J Bacteriol, 177, 3104-3110

30. Aziz, M. M. A., Elgammal, E. W., \& Ghitas, R. G. (2020). Comparative study on modeling by neural networks and response surface methodology for better prediction and optimization of fermentation parameters: Application on thermo-alkaline lipase production by Nocardiopsis sp. strain NRC/WN5. Biocatalysis and Agricultural Biotechnology, 101619, 251-259

31. Patel, R. K., Dodia, M. S., Joshi, R. H., \& Singh, S. P. (2006). Production of extracellular halo-alkaline protease from a newly isolated haloalkaliphilic Bacillus sp. isolated from seawater in Western India. World $\mathrm{J}$ of Microbiology and Biotechnology, 22, 375-382

32. Stoykov, Y. M., Pavlov, A. I., \& Krastanov, A. I. (2015). Chitinase biotechnology: production, purification, and application. Engin. in Life Science, 15, 30-38 
33. Sharma, K. M., Kumar, R., Panwar, S., \& Kumar, A. (2017). Microbial alkaline proteases: Optimization of production parameters and their properties. J of Genetic Engineering and Biotechnology, 15, 115126

34. Kidibule, P. E., Santos-Moriano, P., Jiménez-Ortega, E., Ramírez-Escudero, M., Limón, M. C., Remacha, M. ... Fernández-Lobato, M. (2018). Use of chitin and chitosan to produce new chitooligosaccharides by chitinase Chit42: enzymatic activity and structural basis of protein specificity. Microbiology cell fact, 17, 1-13

35. Karray, A., Alonazi, M., Horchani, H., \& Ben Bacha, A. A. (2021). Novel Thermostable and Alkaline Protease Produced from Bacillus stearothermophilus Isolated from Olive Oil Mill Sols Suitable to Industrial Biotechnology. Molecules, 26, 1139

36. Zhou, Y., Vazquez, A., Wise, A., Warita, T., Warita, K., Bar-Joseph, Z., \& Oltvai, Z. N. (2013). Carbon catabolite repression correlates with the maintenance of near invariant molecular crowding in proliferating E. coli cells. BMC systemic Boilology, 7, 1-13

37. Kumar, S. N., Jacob, J., Reshma, U. R., Rajesh, R. O., \& Kumar, B. S. (2015). Molecular characterization of forest soil based Paenibacillus elgii and optimization of various culture conditions for its improved antimicrobial activity. Front. in Microbiology, 6, 1167-1178

38. Philip, N. V., Koteshwara, A., Kiran, G. A., Raja, S., Subrahmanyam, V. M., \& Chandrashekar, H. R. (2020). Statistical Optimization for Coproduction of Chitinase and Beta 1, 4-Endoglucanase by Chitinolytic Paenibacillus elgii PB1 Having Antifungal Activity. Applied Biochemistry and Biotechnology, 8. https://doi.org/10.1007/s12010-020-03235

39. Elgammal, E. W., Gendy, E., \& Elgamal, A. A., A. G., \&. (2020). Mechanism of action and bioactivities of Cinnamomum zeylanicum essential oil against some pathogenic microbes. Egypt.

Pharmaceutical J, 19, 162-171

40. da Silva, C. R., Silva, M. L. C., Kamida, H. M., Goes-Neto, A., \& Koblitz, M. G. B. (2014). Lytic enzyme production optimization using low-cost substrates and its application in the clarification of xanthan gum culture broth. Food science and Nutrition, 2, 299-307

\section{Tables}

Table 1 Effect of different media on production

\begin{tabular}{|lllll|}
\hline Medium type & \multicolumn{4}{l}{ Enzymatic activity $(\mathrm{U} / \mathrm{mL})$} \\
& Glucanase & Chitinase & Protease & WCL \\
\hline M1 & 1.76 & 0.15 & 70 & 2.37 \\
\hline M2 & 1.38 & 0.08 & 54 & 2.18 \\
\hline M3 & 0.76 & 0.15 & 113 & 11.10 \\
\hline M4 & 20.27 & 11.07 & 108.73 & 15.67 \\
\hline
\end{tabular}


Table 2 Codes and levels of factors studied by Box-Behnken design and response surface methodology

\begin{tabular}{|llllll|}
\hline Factor code & Name & $\begin{array}{l}\text { Low level } \\
(-1)\end{array}$ & $\begin{array}{l}\text { Mean level } \\
(0)\end{array}$ & $\begin{array}{l}\text { high level } \\
(+1)\end{array}$ & Std. Dev. \\
\hline A & Peptone conc. (\%) & 0 & 0.05 & 0.1 & 0.033333333 \\
\hline B & Chitin conc. (\%) & 0 & 0.1 & 0.2 & 0.066666667 \\
\hline C & Baker's yeast conc. (\%) & 0 & 0.5 & 1 & 0.333333333 \\
\hline D & Cell wall conc. (\%) & 0 & 0.3 & 0.6 & 0.2 \\
\hline
\end{tabular}

Table 3 BBD for studying the production of different enzymes in relation to four main nutritional components 


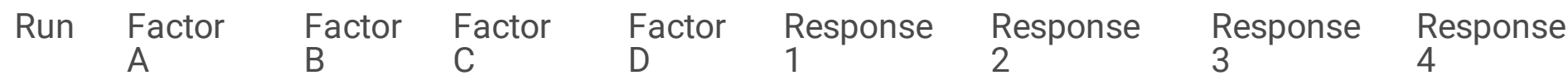

Peptone Chitin Baker's Cell Chitinase Glucanase Protease WCL conc. conc. yeast wall activity activity activity

$(\%)$

conc. conc. $(\mathrm{U} / \mathrm{ml})$

$(\mathrm{U} / \mathrm{ml})$

$(\mathrm{U} / \mathrm{ml})$

$(\mathrm{U} / \mathrm{ml})$

(\%)

\begin{tabular}{|c|c|c|c|c|c|c|c|c|}
\hline 1 & 0 & 0.1 & 0 & 0.3 & 3.1 & 17.1 & 56.8 & 32.5 \\
\hline 2 & 0.05 & 0.1 & 1 & 0.6 & 4.4 & 29.1 & 137.2 & 10.0 \\
\hline 3 & 0.05 & 0 & 0.5 & 0 & 10.0 & 19.7 & 75.2 & 35.0 \\
\hline 4 & 0.05 & 0.1 & 0 & 0.6 & 7.5 & 18.7 & 129.2 & 41.0 \\
\hline 5 & 0.05 & 0.2 & 0.5 & 0.6 & 12.0 & 26.2 & 130.0 & 31.0 \\
\hline 6 & 0.05 & 0.1 & 0.5 & 0.3 & 10.3 & 22.6 & 99.0 & 12.0 \\
\hline 7 & 0.05 & 0.1 & 0.5 & 0.3 & 9.2 & 18.6 & 125.6 & 18.0 \\
\hline 8 & 0.05 & 0.1 & 0.5 & 0.3 & 13.7 & 19.6 & 101.6 & 17.0 \\
\hline 9 & 0.05 & 0.2 & 0.5 & 0 & 12.1 & 16.9 & 90.4 & 45.0 \\
\hline 10 & 0.05 & 0 & 1 & 0.3 & 2.1 & 28.2 & 130.8 & 20.0 \\
\hline 11 & 0.05 & 0 & 0.5 & 0.6 & 7.9 & 20.4 & 115.6 & 42.0 \\
\hline 12 & 0 & 0.1 & 0.5 & 0.6 & 1.7 & 21.5 & 130.0 & 14.5 \\
\hline 13 & 0.1 & 0.2 & 0.5 & 0.3 & 15.0 & 22.9 & 127.6 & 43.5 \\
\hline 14 & 0.1 & 0.1 & 0 & 0.3 & 11.6 & 19.0 & 115.8 & 41.0 \\
\hline 15 & 0 & 0.1 & 1 & 0.3 & 4.7 & 21.4 & 90.0 & 37.0 \\
\hline 16 & 0.1 & 0.1 & 0.5 & 0 & 3.3 & 21.0 & 123.6 & 31.0 \\
\hline 17 & 0.05 & 0.2 & 1 & 0.3 & 8.5 & 22.1 & 129.8 & 29.0 \\
\hline 18 & 0.1 & 0.1 & 1 & 0.3 & 6.0 & 23.0 & 123.2 & 41.5 \\
\hline 19 & 0.05 & 0.2 & 0 & 0.3 & 7.1 & 15.0 & 80.6 & 40.1 \\
\hline 20 & 0 & 0 & 0.5 & 0.3 & 11.9 & 21.4 & 103.2 & 58.0 \\
\hline 21 & 0 & 0.2 & 0.5 & 0.3 & 15.8 & 17.9 & 101.8 & 63.0 \\
\hline 22 & 0.05 & 0.1 & 1 & 0 & 1.7 & 21.6 & 116.8 & 40.5 \\
\hline 23 & 0.05 & 0.1 & 0 & 0 & 7.4 & 7.2 & 64.2 & 35.0 \\
\hline 24 & 0.05 & 0 & 0 & 0.3 & 4.9 & 9.1 & 80.0 & 61.0 \\
\hline 25 & 0.1 & 0 & 0.5 & 0.3 & 9.1 & 18.9 & 122.8 & 69.0 \\
\hline
\end{tabular}




$\begin{array}{lllllllll}26 & 0 & 0.1 & 0.5 & 0 & 12.0 & 10.8 & 93.2 & 63.0 \\ 27 & 0.1 & 0.1 & 0.5 & 0.6 & 11.7 & 19.5 & 132.4 & 51.0\end{array}$

Table 4 ANOVA analysis for modeling the production of different enzymes 
Model specification

\begin{tabular}{ll}
$\begin{array}{l}\text { Type of } \\
\text { model }\end{array}$ & Quadratic \\
\hline p-value & 0.0102 \\
$\begin{array}{l}\text { Significance } \\
\text { and validity } \\
\text { of model }\end{array}$ & $\begin{array}{l}\text { Significant. There } \\
\text { is only a 1.02\% } \\
\text { chance that a }\end{array}$ \\
$\begin{array}{l}\text { "Model F-Value" } \\
\text { could occur due to } \\
\text { noise. }\end{array}$
\end{tabular}

Lack of Fit $\quad 0.5332$

(not significant)
Glucanase

Two-Factor Interaction (2FI)

$<0.0001$

Significant. There is only a $0.01 \%$ chance that a "Model F-Value" could occur due to noise.

0.4684

(not significant)
Protease

Linear

$<0.0001$

Significant. There is only a $0.01 \%$ chance that a "Model F-Value" could occur due to noise.

0.6761

(not significant)
WCL

Quadratic

0.0016

Significant. There is only a $0.16 \%$ chance that a "Model F-Value" could occur due to noise.

0.1180

(not significant)

Fitness

parameters

0.8248

0.8432

0.7039

0.8783

$\mathrm{R}^{2}$

0.6205

0.7453

0.6501

0.7364

Adj. $\mathrm{R}^{2}$

6.640

10.505

11.788

9.351

Signal/noise ratio

Significant terms

\section{Factors}

showing

interaction

Model

equation
$B, C 2, A D$

A with D

Chitinase activity

$=$

$$
+9.05617
$$

-43.1346 * A

-20.65496 * B

$+17.47349 * \mathrm{C}$

$-6.05064 * D$

$+96.08375 * A$ * $B$

$-72.22092 * A$ * $C$

+312.55 * $A$ * $D$

+21.19924 * $B$ * $C$

+16.95804 * $B$ * $D$

$+4.21633 * C * D$
A with $D$

B with C

$C, D, A D, B C$

Glucanase activity

$=+6.79894$

+49.13167 * A

$-6.8325 * B$

+18.1425 * C

+17.2425 * $D$

+375.975 * $A$ * $B$

$-2.81 * A * C$

$-205.2 * A * D$

$-60.705 * B * C$

+70.5375 * $B$ * $D$

$-6.84 * C * D$
A, C, D

No interactions

A with $D$

C with D

Protease activity =

$+57.11852$

+284 * A

+27.16667 * $\mathrm{B}$

+33.53333 * $C$

+58.61111 * $D$
$C, A D, C D, A^{2}, B^{2}$
Cell wall lytic

enzymes activity = $+80.23333$

-942.33333 * A

-346.5 * B

$-27.33333 * C$

$-68.72222 * D$

$-1525 * A$ * $B$

$-40 * A * C$

+1141.667 * $A$ * $D$

$+149.5 * B$ * $C$

$-175 * B * D$

$-60.83333 * C * D$ 

$-115.26529 * A^{2}$
$+7873.33333 * A^{2}$
$+103.29211 * B^{2}$
$+1863.33333 * B^{2}$
$-19.63679 * C^{2}$
$+20.53333 * C^{2}$
$-22.92389 * D^{2}$
$+71.48148 * D^{2}$

Table 5 Composition of the four media developed on BBD and RSM for highest production of each enzyme with predicted and verified productivity

\begin{tabular}{|c|c|c|c|c|c|}
\hline & & Medium I & Medium II & Medium III & Medium IV \\
\hline $\begin{array}{l}\text { Model used t } \\
\text { medium }\end{array}$ & develop the & $\begin{array}{l}\text { Quadratic model } \\
\text { of chitinase }\end{array}$ & $\begin{array}{l}2 \mathrm{FI} \text { model of } \\
\text { glucanase }\end{array}$ & $\begin{array}{l}\text { Linear model } \\
\text { of protease }\end{array}$ & $\begin{array}{l}\text { Quadratic } \\
\text { model of WCL }\end{array}$ \\
\hline Structure of & Baker's yeast & 0.33 & 0.91 & 0.77 & 0.38 \\
\hline & Coml. (10) & 0.20 & 0.00 & 0.13 & 0.01 \\
\hline & $\begin{array}{l}\text { Chitin conc. } \\
(\%)\end{array}$ & 0.45 & 0.51 & 0.52 & 0.45 \\
\hline & $\begin{array}{l}\text { Cell wall } \\
\text { conc. }(\%)\end{array}$ & 0.10 & 0.00 & 0.08 & 0.10 \\
\hline & $\begin{array}{l}\text { Peptone } \\
\text { conc. (\%) }\end{array}$ & & & & \\
\hline Enzyme of $h$ & hest & Chitinase, & Glucanase, & Protease, & WCL, \\
\hline the expected & & $16.93 \mathrm{U} / \mathrm{ml}$ & $28.91 \mathrm{U} / \mathrm{ml}$ & $138.43 \mathrm{U} / \mathrm{ml}$ & $70.85 \mathrm{U} / \mathrm{ml}$ \\
\hline $\begin{array}{l}\text { The yield as } \\
\text { validated }\end{array}$ & actically & $14.97 \mathrm{U} / \mathrm{ml}$ & $27.89 \mathrm{U} / \mathrm{ml}$ & $137.59 \mathrm{U} / \mathrm{ml}$ & $65.28 \mathrm{U} / \mathrm{ml}$ \\
\hline $\begin{array}{l}\text { * The structu } \\
\text { components } \\
\mathrm{NaNO}_{3}: 0.1 .\end{array}$ & $\begin{array}{l}\text { concerned witl } \\
\text { ere as follow (\%) }\end{array}$ & $\begin{array}{l}\text { he main compon } € \\
\mathrm{~K}_{2} \mathrm{HPO}_{4:}: .3, \mathrm{KH}_{2}\end{array}$ & $\begin{array}{l}\text { ts targeted thr } \\
\mathrm{O}_{4} ; 0.2, \mathrm{MgSO}\end{array}$ & $\begin{array}{l}\text { gh BBD and RS } \\
\mathrm{H}_{2} \mathrm{O}: 0.03 \text {, Gluc }\end{array}$ & $\begin{array}{l}\text { Other medium } \\
\text { e: } 0.02 \text { and }\end{array}$ \\
\hline
\end{tabular}

Table 6 Pearson's correlation coefficient $(r)$ for the relation between production of different enzymes

\begin{tabular}{|lllll|}
\hline & Chitinase & Glucanase & Protease & WCL \\
\hline Chitinase & 1 & -0.14 & -0.01 & 0.35 \\
\hline Glucanase & -0.14 & 1 & 0.69 & -0.49 \\
\hline Protease & -0.01 & 0.69 & 1 & -0.21 \\
WCL & 0.35 & -0.49 & -0.21 & 1 \\
\hline
\end{tabular}

Table 7 Composition, predicted and verified productivity of the optimum medium for coproduction of all enzymes 


\section{Composition of the medium (main components)}

\begin{tabular}{ll} 
Baker's yeast conc. (\%) & 0.21 \\
\hline Chitin conc. (\%) & 0.2 \\
Cell wall conc. (\%) & 0.6 \\
\hline Peptone conc. (\%) & 0.1
\end{tabular}

\section{Amount of produced enzymes}

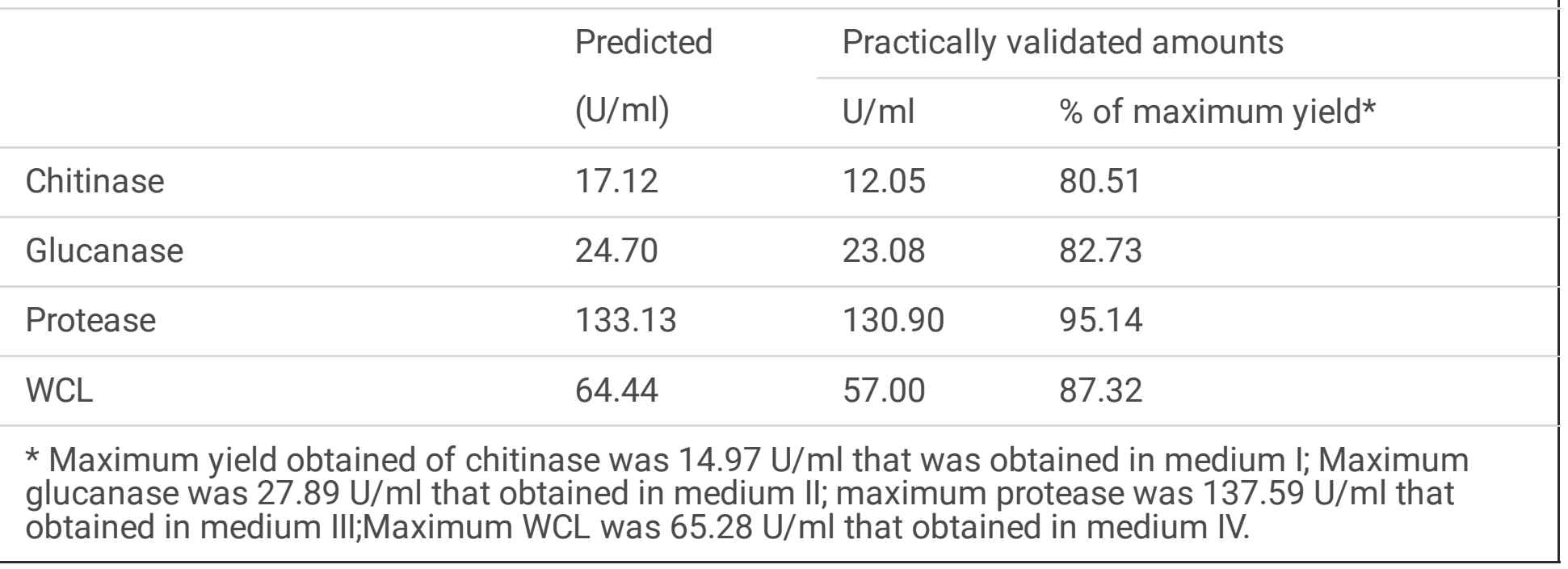

Table 8 Suitability of the different media for the coproduction of all enzymes

Productivity\%* of the different enzymes in the four media

\begin{tabular}{llll} 
Medium I & Medium II & Medium III & Medium IV \\
\hline 100\% Chitinase & $100 \%$ Glucanase & $100 \%$ Protease & $100 \%$ WCL \\
67.99\% Glucanase & $51.14 \%$ Chitinase & $63.80 \%$ Chitinase & $72.41 \%$ Chitinase \\
85.81\% Protease & $84.78 \%$ Protease & $89.21 \%$ Glucanase & $68.35 \%$ Glucanase \\
$84 \%$ WCL & $57.12 \%$ WCL & $26.88 \%$ WCL & $74.42 \%$ Protease
\end{tabular}

*Expressed as a percentage of enzyme concentration to the maximum amount obtained; chitinase activity was expressed as percentage of $14.97 \mathrm{U} / \mathrm{ml}$; glucanase activity was a percentage of 27.89 $\mathrm{U} / \mathrm{ml}$; protease activity was a percentage of $137.59 \mathrm{U} / \mathrm{ml}$; lytic activity was a percentage of 65.28 $\mathrm{U} / \mathrm{ml}$.

\section{Figures}




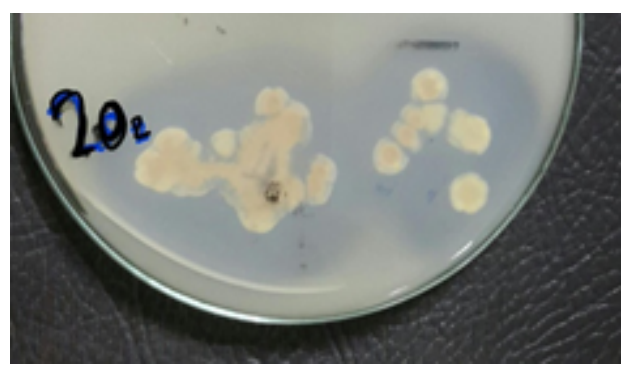

Figure 1

Inhibition zone around the isolate $20 \mathrm{~S}$

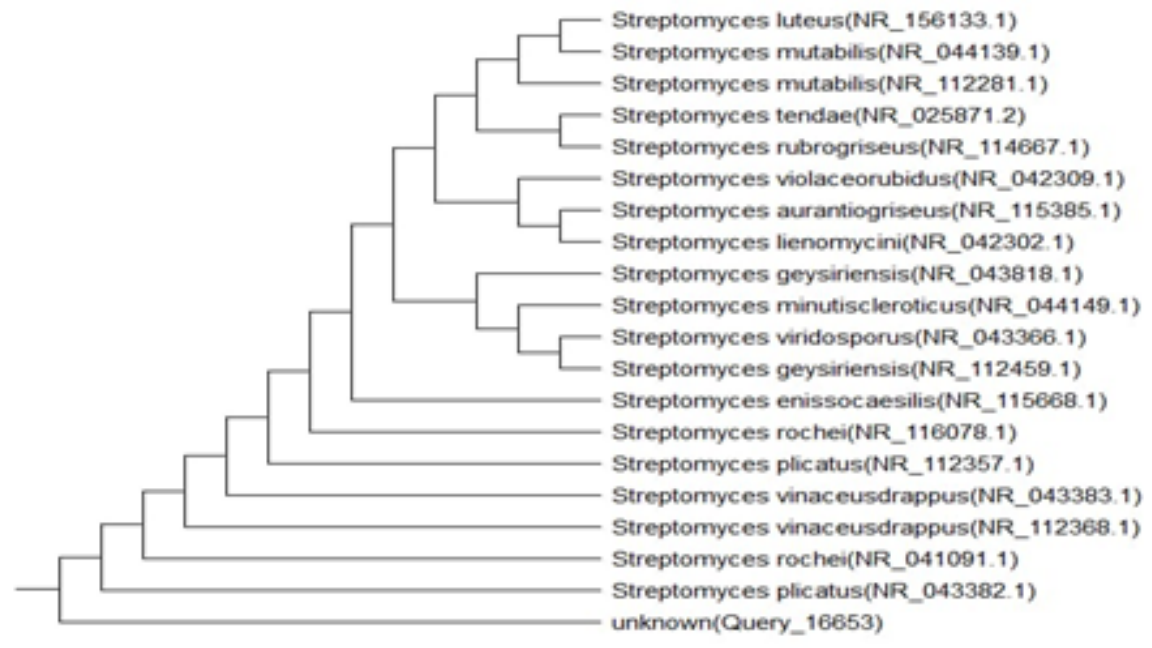

Figure 2

Phylogenetic tree of Streptomyces rochei strain MZ227230 


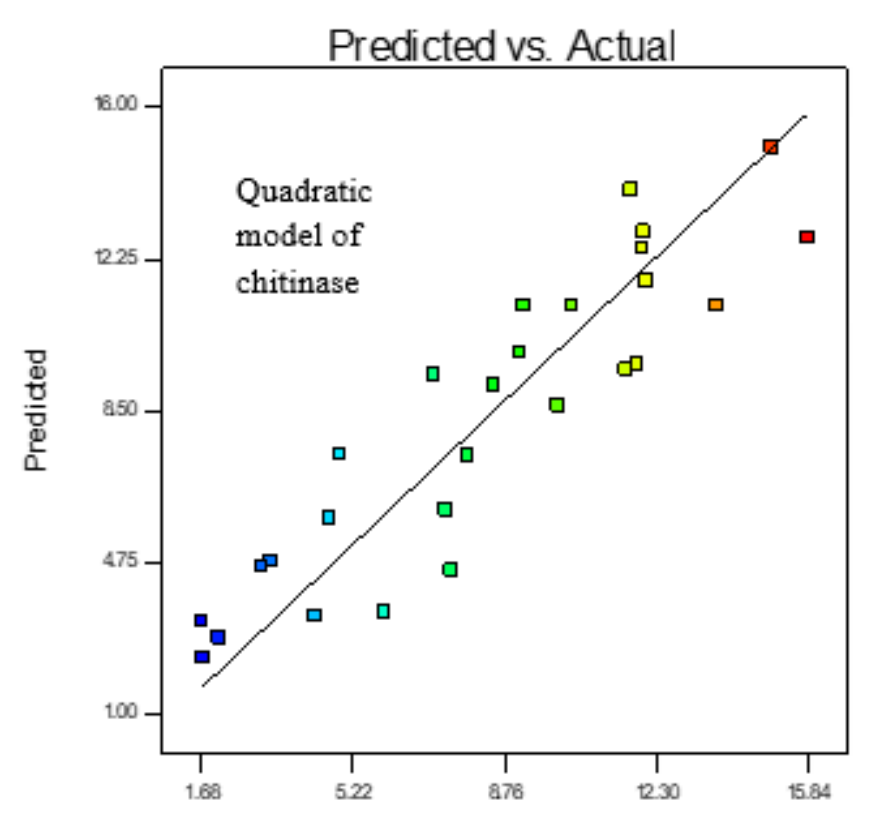

Actual

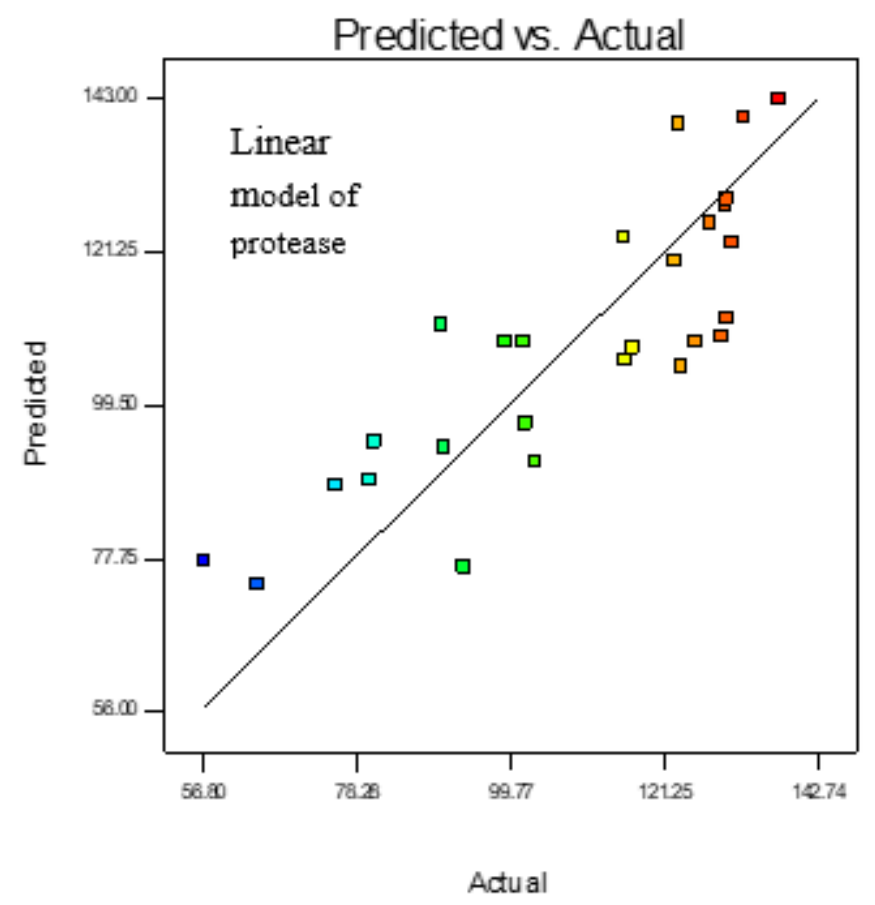

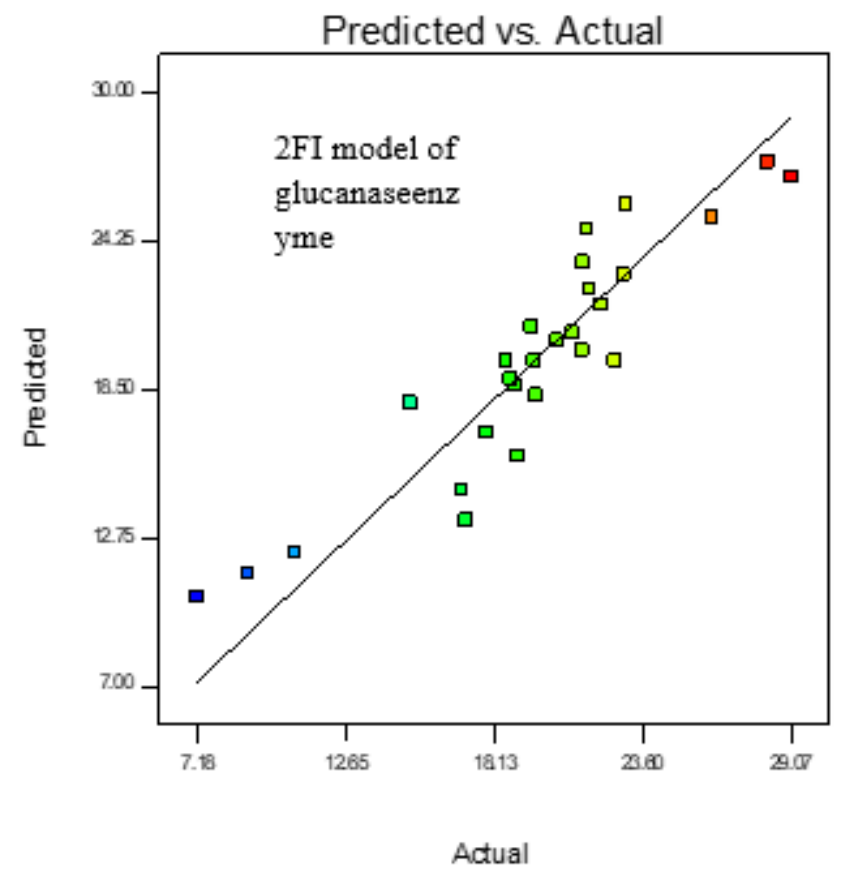

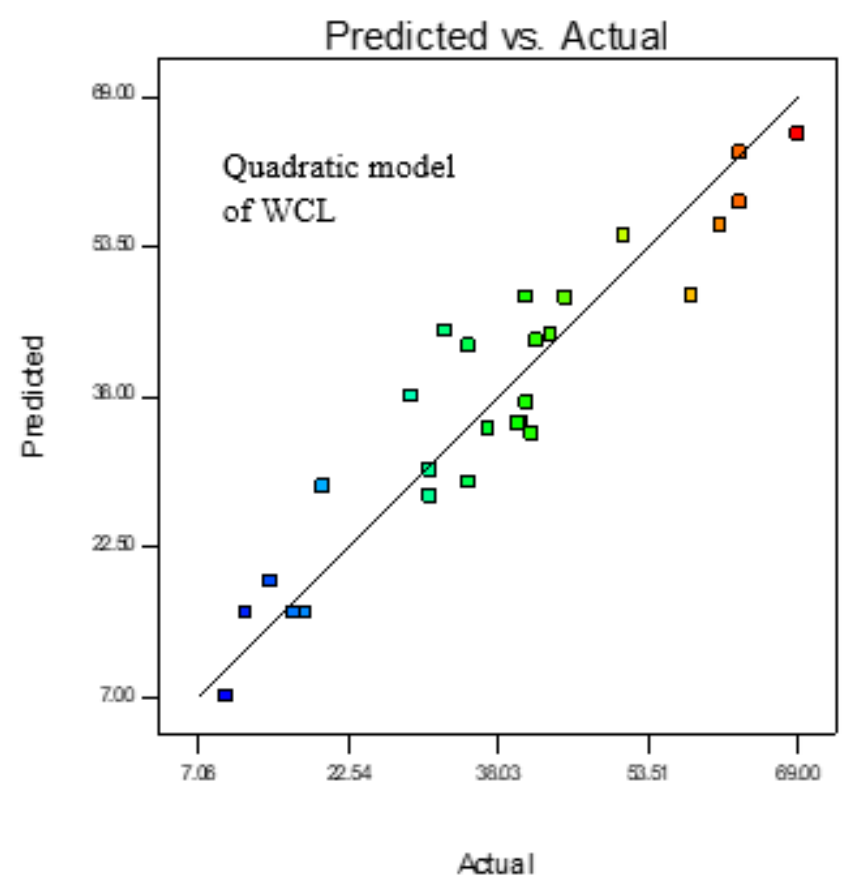

Figure 3

Relation between prediceted enzyme concentration versus actual concentration for the models describing production of different enzymes 

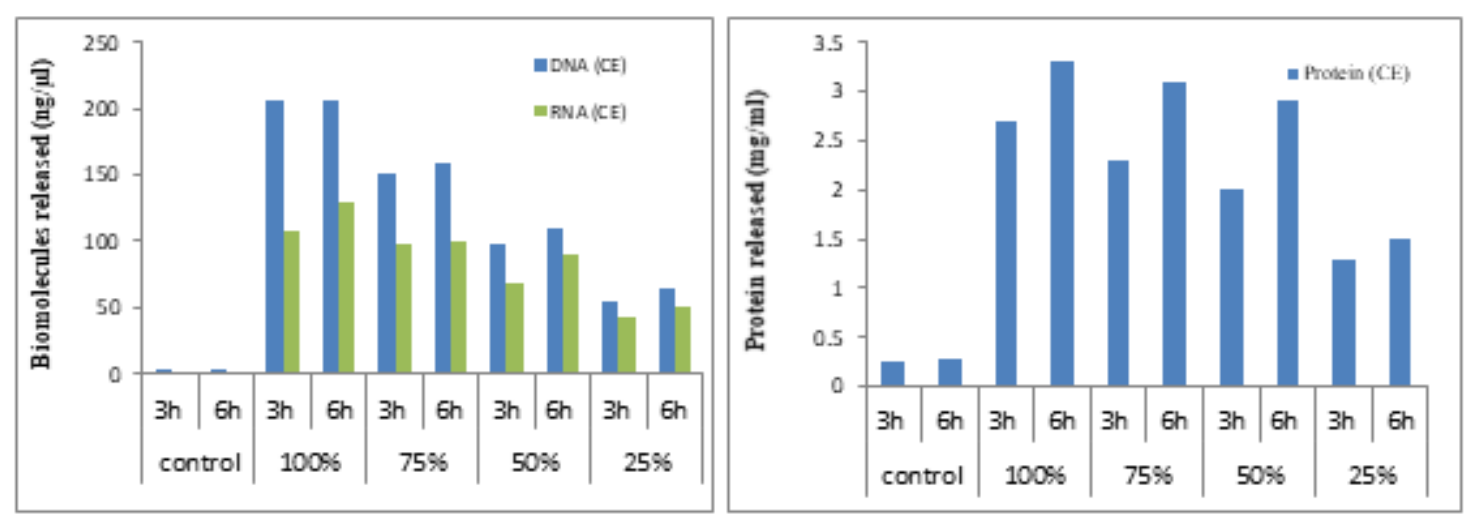

Figure 4

Quantity of released biomolecules from C. albicans ATCC10231 treated with crude culture filtrate (CE) 